\title{
Antioxidant Capacity of Momordica charantia Extract and its Protective Effect on Testicular Damage in Valproic Acid-Induced Rats
}

\author{
Capacidad Antioxidante del Extracto de Momordica charantia y su Efecto \\ Protector sobre el Daño Testicular en Ratas Inducidas con Ácido Valproico
}

Chanwit Maneenin $^{1,2}$; Jaturon Burawat ${ }^{1}$; Naowarat Maneenin ${ }^{3}$; Somsak Nualkaew ${ }^{4}$; Supatcharee Arun ${ }^{1,5}$; Apichakan Sampannang ${ }^{1,5}$ \& Sitthichai Iamsaard ${ }^{1,5}$

MANEENIN, C.; BURAWAT, J.; MANEENIN, N.; NUALKAEW, S.; ARUN, S.; SAMPANNANG, A. \& IAMSAARD, S. Antioxidant capacity of Momordica charantia extract and its protective effect on testicular damage in valproic acid-induced rats. Int. $J$. Morphol., 36(2):447-453, 2018.

SUMMARY: Although Momordica charantia (MC) has preventive effects on tissue injuries, antioxidant capacity and protective effect of MC pulp and peel (MCP) on valproic acid (VPA)-testicular damage have never been reported. Fresh MCPs were aqueous extracted and determined for antioxidant capacity and momordicine I level by HPLC. Male rats were divided into 5 groups (control, VPA $(500 \mathrm{mg} / \mathrm{kgBW}), \mathrm{MCP} 20 / 40 /$ or $80 \mathrm{mg} / \mathrm{kgBW}+\mathrm{VPA})$. In 30 experimental days, animals were pretreated with different doses of MCPs for 20 days before VPA injection for 10 consecutive days. Sperm concentration, testosterone hormone, and testicular histology of all groups were investigated. Expressions of testicular tyrosine phosphorylated and steroidogenic acute regulatory (StAR) proteins were examined by Western blot. Results showed that MCP contains TPC (39.24 $\pm 0.65 \mathrm{ug} / \mathrm{mg}$ garlic acid), antioxidant capacities (FRAP=33.08 $\pm 0.21 \mathrm{ug} /$ $\mathrm{mg}$ ascorbic acid equivalent, IC50 of DPPH=389.8 $\pm 3.20 \mathrm{ug} / \mathrm{ml}$ ), and momordicine I (404.9 mg/g MCP). Sperm concentration in MCP80+VPA group was increased as compared to VPA group. Testosterone level in MCP treated groups was significantly increased. MCP protected testicular damage and could prevent the decrease of StAR and a 50-kDa phosphorylated protein expression in VPAtreated testis. In conclusion, MCP has antioxidant activities and can prevent male reproductive toxicity in VPA-induced rats.

KEY WORDS: Momordica charantia; Momordicine I; Antioxidant capacity; Testicular damage; Valproic acid.

\section{INTRODUCTION}

Valproic acid or valproate (VPA) is commonly used for treatments in many neurological disorders such as panic attack, anorexia nervosa, anxiety disorder, posttraumatic stress disorder, and psychiatric conditions (Löscher, 2002). Due to the property in histone deacetylase inhibition, VPA has been used in treating of many cancers (Gelder et al., 2006; Berendsen et al., 2012; Glister et al., 2012). Although VPA has various therapeutic properties, adverse effects on the gastrointestinal, neurological, hematological, and endocrine systems have been reported (Isojärvi, 2008; Taubøll et al., 2008). In addition, VPA can cause fibrosarcomas and adenocarcinomas in the uterus (Watkins et al., 1992; Jentink et al., 2010; Witczak et al., 2010). Indeed, it has been reported to have adverse effects such as decreasing of sex hormones and sperm qualities (Nishimura et al., 2000; Herzog et al., 2004; Hamza \& Amin, 2007; Khan et al., 2011; Iamsaard et al., 2017a,b; Sukhorum \& Iamsaard, 2017). Currently, herbal medicines have been studied for searching of alternative VPA treatments (Sakr et al., 2014; Iamsaard et al., 2015, 2017b; Sukhorum et al., 2016).

Momordica charantia (MC) Linn, also called Mara Kee Nok in Thai, is a tropical vine belonging to Cucurbitaceae family. $\mathrm{MC}$ was reported to have antioxidant

\footnotetext{
${ }^{1}$ Department of Anatomy, Faculty of Medicine, Khon Kaen University, Khon Kaen, Thailand.

${ }^{2}$ Department of Anatomy, College of Medicine and Public health, Ubonratchathani University,Ubonratchathani, Thailand.

${ }^{3}$ Department of Epidemiology and Biostatistics, Faculty of Public health, Khon Kaen University, Khon Kaen, Thailand.

${ }^{4}$ Department of Pharmaceutical Sciences, Faculty of Pharmacy, Mahasarakham University, Mahasarakham, Thailand.

${ }^{5}$ Reproductive Biomedicine Research Unit, Faculty of Medicine, Khon Kaen University, Khon Kaen, 40002, Thailand.
} 
activity (Ghous et al., 2015), antidiabetic property (Blum et al., 2012), and anticancer property (Lee-Huang et al., 1995). In addition, a literature review has documented that $\mathrm{MC}$ is commonly used to treat the pathological conditions including dysmenorrhea, eczema, galactagogue, gout, jaundice, nephrolithiasis, leucorrhea, pneumonia, psoriasis, rheumatism, and scabies (Grover \& Yadav, 2004). Previous studies have demonstrated the protective effects of MC on damaged tissues such as liver, brain, stomach, and heart (Ozbakis, Dengiz \& Gürsan, 2005; Abas et al., 2014; Duan et al., 2015; Deng et al., 2017). However, protective effects of MC against reproductive impairment induced by VPA have never been documented. Therefore, the aim of this study was to investigate the antioxidant activities and protective effects of MC pulp and peel extract on testicular damage in VPA-induced rats.

\section{MATERIAL AND METHOD}

Plant collection and extraction. Momordica charantia trees were planted at Ban Sawang farm in Khon Kaen province, Thailand. The plant samples were botanically authenticated by Professor Pranom Chantaranothai, a taxonomist in Department of Biology, Faculty of Science, Khon Kaen University, where the voucher specimen was deposited (no. Chanwit Maneenin 01 [KKU]). The fresh mature fruits of Momordica charantia were harvested in June, 2016. The white arils were discarded to collect pulp and peel (MCP). Such samples were aqueous extracted and further dried by using the spray dryer (Nitro A/S-Gladsaxeveg-305-DK2860, Soeborg, Denmark). The extraction powder yields were approximately $1.47 \%$.

Total phenolic content determination. Total phenolic contents (TPC) in MCP extract were measured using the Folin-Ciocalteu reagent method as previously described (Singleton et al., 1999; Burawat et al., 2016). In brief, 0.2 $\mathrm{ml}$ of MCP aqueous solution ( $2 \mathrm{mg}$ dried extract $/ \mathrm{ml}$ ) was mixed with $1 \mathrm{ml}$ of the Folin-Ciocalteu reagent $(10 \%$, v/v) for $5 \mathrm{~min}$. Then the mixed solution was added with $3 \mathrm{ml}$ of $0.2 \mathrm{~g} / \mathrm{ml}$ sodium carbonate for $2 \mathrm{~h}$ (room temperature in a dark room). The absorbance was measured in triplicate at $765 \mathrm{~nm}$ using an ultraviolet-visible spectrophotometer (Jasco V530, Japan). Gallic acid was used as a positive control by plotting five concentrations $(0.040,0.064,0.080,0.120$, and $0.160 \mathrm{mg} / \mathrm{ml}$ gallic acid) to perform a standard curve.

DPPH radical scavenging assay. The radical scavenging activity of MCP extract was determined as previously described (Brand-Williams et al., 1995; Iamsaard et al., 2014). To compare the radical scavenging ability of MCP extract to standard ascorbic acid, $2 \mathrm{ml}$ of each MCP concentrations $(0.08,0.24,0.40$, and $0.56 \mathrm{mg} / \mathrm{ml})$ was mixed with 2,2-diphenyl-1-picrylhydrazyl (DPPH) in methanol for $30 \mathrm{~min}$ at room temperature in the dark room. Then, absorbance was triplicately recorded at $517 \mathrm{~nm}$ using an ultraviolet-visible spectrophotometer. The percentage of radical scavenging activity in all samples was calculated according to following formula described by Brand-Williams et al.

DPPH radical scavenging $\%=[(\mathrm{DPPH}$ absorbance - sample absorbance) x 100] /DPPH absorbance

In addition, ascorbic acid equivalent antioxidant capacity (AEAC) of MCP extract (100 g) was calculated from the half maximal inhibitory concentration (IC50) of standard ascorbic acid as previously described (Chew et al., 2011).

Reducing power capacity assay. Reducing power capacity was estimated by using FRAP assay as previously described (Benzie \& Strain, 1996; Burawat et al.). Ascorbic acid in four concentrations $(0.00192,0.00960,0.0240$, and 0.0480 $\mathrm{mg} / \mathrm{ml}$ ) was used as positive standard to plot a calibration curve. Then, $0.1 \mathrm{ml}$ of MCP solution $(1 \mathrm{mg} / \mathrm{ml})$ was mixed with $3 \mathrm{ml}$ of FRAP reagent $(300 \mathrm{mmol} / \mathrm{l}$ acetate buffer, 10 $\mathrm{mmol} / \mathrm{l} \mathrm{TPTZ}, 20 \mathrm{mmol} / \mathrm{FeCl}_{3}$ [10:1:1, v/v/v]) for $20 \mathrm{~min}$ in a dark room. Then, the absorbance was recorded at 593 $\mathrm{nm}$ by using an ultraviolet-visible spectrophotometer. When compared with standard curve, the reducing power capacity of MCP extract was reported as $\mathrm{ug} / \mathrm{mg}$ ascorbic acid equivalent.

Momordicin content assay by high performance liquid chromatography (HPLC). In standard and sample preparations, momordicine I was dissolved with $100 \%$ acetonitrile (HPLC grade) to gain 0.00625, 0.0125, 0.025, and $0.05 \mathrm{mg} / \mathrm{ml}$ concentrations and $0.1 \mathrm{mg} / \mathrm{ml}$ of MCP solution was prepared by dissolving in $1 \mathrm{mg}$ of MCP powder extract with $1 \mathrm{ml}$ acetonitrile. These solutions were filtered (Whatman, $0.2 \mu \mathrm{m}$ ) before injection to remove any nonedissolved particles. HPLC system (Shimadzu, Japan) was equipped with pump (model LC-20AD), Photo-diode array detector, and auto sampler (model SIL-20AHT). The separation of momordicine I was carried out on a reversedphase $5 \mu \mathrm{m}$ C18 Inertsil ${ }^{\circledR}$ ODS-4 column $(250 \mathrm{~mm}$ x 4.6 $\mathrm{mm}$ ) under isocratic conditions and injection volume of 20 $\mathrm{ml}$. Acetonitrile was used as the mobile phase solvent running for $15 \mathrm{~min}(1 \mathrm{ml} / \mathrm{min}$ flow rate). Absorbance of the standard was measured at $260 \mathrm{~nm}$. Data acquisition was done with CLASS-VP software. For determination the level of momordicine I in the extract, area under MCP curve was calibrated by using a standard curve. 
MANEENIN, C.; BURAWAT, J.; MANEENIN, N.; NUALKAEW, S.; ARUN, S.; SAMPANNANG, A. \& IAMSAARD, S. Antioxidant capacity of Momordica charantia extract and its protective effect on testicular damage in valproic acid-induced rats. Int. J. Morphol., 36(2):447-453, 2018.

Experimental animals. Forty male Wistar rats (6-8 weeks) were purchased from the National Laboratory Animal Center, Salaya, Nakhon Pathom, Thailand and then they were transferred and housed $\left(23 \pm 2{ }^{\circ} \mathrm{C}, 350-400 \mathrm{Lux}, 30\right.$ $60 \%$ of relative humidity, and under a $12 \mathrm{~h}$ light/dark cycle) at the Northeast Laboratory Animal Center, Khon Kaen University, Thailand. The rats were randomly divided into five groups ( $n=8$ each group) including control, VPA, MCP20+VPA, MCP40+VPA, and MCP80+VPA groups. Treatments on experimental and control groups were shown in Table I. After consecutive 30-day treatments, the animals were euthanized and sacrificed to collect the blood and male reproductive organs. This study was approved by Animal Ethics Committee of Khon Kaen University (IACUC-KKU-1/B1).

Testosterone assay. At the end of experiment, animals were anesthetized and then their blood was immediately collected by cardiac puncture. The blood samples were centrifuged at $13000 \mathrm{rpm}, 4{ }^{\circ} \mathrm{C}$, for $7 \mathrm{~min}$. To assay the testosterone levels, the serum was subsequently sent to the Radiology Unit, Srinagarind Hospital, Faculty of Medicine, Khon Kaen University, Thailand.

Sperm count assay. The left caudal epididymis plus vas deferens were dissected out to squeeze sperm fluid. Then, epididymal fluid was dipped into $1 \mathrm{ml}$ of phosphate buffered saline (PBS, $37^{\circ} \mathrm{C}, \mathrm{pH}$ 7.4) and further centrifuged at $5000 \mathrm{rpm}, 25^{\circ} \mathrm{C}$, for 2 min to separate the mature sperm pellet from the fluid. In all groups, the sperm pellets were re-suspended with $1 \mathrm{ml}$ of PBS. The sperm suspension was dropped on Neubauer counting chamber to count and calculate sperm concentration in triplicate examinations (Iamsaard et al., 2013).

Histopathology. All right testes were subsequently collected, weighed, and immediately fixed with $10 \%$ formalin in phosphate buffered saline (PBS). To investigate the testicular damage, samples were embedded in paraffin, sectioned at $5 \mu \mathrm{m}$ thicknesses, and stained with hematoxylin and eosin. Then, all testicular sections were observed and captured under a Nikon light ECLIPSE E200 microscope equipped with a DXM1200 digital camera.

Western blot analysis. To extract total proteins, fresh left testes were homogenized with radioimmunoprecipitation assay (RIPA) buffer (Cell Signaling Technology Inc., USA) containing a cocktail of protease inhibitors (Sigma Inc., USA). Then the homogenate was centrifuged at $12000 \mathrm{rpm}$ at $4{ }^{\circ} \mathrm{C}$ for $10 \mathrm{~min}$ to collect testicular lysate. The protein concentration was measured using a NanoDrop Spectrophotometer (NanoDrop Technologies Inc., USA) at absorbance of $280 \mathrm{~nm}$. Testicular lysate $(80 \mathrm{mg})$ of each group was loaded and separated on $10 \%$ sodium dodecyl sulfate polyacrylamide gel electrophoresis (SDS-PAGE). In addition, proteins on SDS-PAGE were stained by Coomassie blue to confirm the equal amount of total proteins of each lane. To determine the expression of StAR and tyrosine phosphorylated proteins, the separated proteins were transferred onto nitrocellulose membrane and incubated with $5 \%$ skim milk in $0.1 \%$ PBST $(0.1 \%$ Tween- $20,0.01$ mol/ lPBS, pH 7.4) for $1 \mathrm{~h}$ to non-specific blocking. Then, blocked membranes were incubated with StAR antibody (1:1000 [v/ v] dilution; Santa Cruz Biotechnology Inc., USA), $\beta$-actin antibody (1:2000 [v/v] dilution; Santa Cruz Biotechnology Inc., USA), or anti-phosphotyrosine antibody (1:2000 (v/ v); Millipore Co., USA) at $4{ }^{\circ} \mathrm{C}$ overnight. After washing non-specific bindings with $0.05 \%$ PBST, the membranes were incubated with goat anti-rabbit IgG secondary antibody (conjugated with horseradish peroxidase [HRP]) for StAR antibody or goat anti-mouse secondary antibody (conjugated with HRP) for $\beta$-actin and phosphotyrosine antibodies ( $2 \mathrm{~h}$ at room temperature). Then, antigen-antibody complex was detected by using enhanced chemiluminescence substrate under gel doct 4 (Image Quant 400, GH Healthcare, USA). For intensity analysis, the ImageJ program (Version 1.49p) was used to measure the intensity of target proteins.

Statistical analysis. All data were represented as mean \pm standard deviation (SD). The student $t$-test was used to examine and analyze the significant difference between two groups using SPSS statistics 17.0 software. The pvalue of $<0.05$ was considered as a significant difference.

Table I. Treatment periods on each group of rats.

\begin{tabular}{llc}
\hline \multirow{2}{*}{ Groups } & \multicolumn{1}{c}{ Day 1-30 } & \multicolumn{1}{c}{ Dreatments $21-30$} \\
\cline { 2 - 3 } & \multicolumn{1}{c}{ (orogastric tube) } & \multicolumn{1}{c}{ (i.p. injection) } \\
\hline Control & Distilled water, $1 \mathrm{ml}$ & Saline, $0.5 \mathrm{ml}$ \\
VPA & Distilled water, $1 \mathrm{ml}$ & $500 \mathrm{mg} / \mathrm{kgBW}$ of VPA, $0.5 \mathrm{ml}$ \\
MCP20+VPA & $20 \mathrm{mg} / \mathrm{kgBW}$ of MCP extract, $1 \mathrm{ml}$ & $500 \mathrm{mg} / \mathrm{kgBW}$ of VPA, $0.5 \mathrm{ml}$ \\
MCP40+VPA & $40 \mathrm{mg} / \mathrm{kgBW}$ of MCP extract, $1 \mathrm{ml}$ & $500 \mathrm{mg} / \mathrm{kgBW}$ of VPA, $0.5 \mathrm{ml}$ \\
MCP80+VPA & $80 \mathrm{mg} / \mathrm{kgBW}$ of MCP extract, $1 \mathrm{ml}$ & $500 \mathrm{mg} / \mathrm{kgBW}$ of VPA, $0.5 \mathrm{ml}$ \\
\hline
\end{tabular}


MANEENIN, C.; BURAWAT, J.; MANEENIN, N.; NUALKAEW, S.; ARUN, S.; SAMPANNANG, A. \& IAMSAARD, S. Antioxidant capacity of Momordica charantia extract and its protective effect on testicular damage in valproic acid-induced rats. Int. J. Morphol., 36(2):447-453, 2018.

\section{RESULTS}

Total phenolic contents and antioxidant capacity. From the calibration curves of the garlic acid, a standard marker $\left(\mathrm{y}=4.0928 \mathrm{x}-0.1067, \mathrm{R}^{2}=0.98\right)$, total phenolic contents (TPC) of MCP calculated were $39.24 \pm 0.65 \mathrm{ug} / \mathrm{mg}$ garlic acid (Table II.). In addition, the antioxidant capacity results were shown in Table II. The reducing power capacity of MCP was $33.08 \pm 0.21 \mathrm{ug} / \mathrm{mg}$ ascorbic acid equivalent and the half maximal inhibitory concentration (IC50) of MCP extract was $389.8 \pm 3.20 \mathrm{ug} / \mathrm{ml}$. Moreover, AEAC of MCP was $1479.44 \pm 12.28 \mathrm{mg}$ ascorbic acid/100 g powdered extract (Table II).

Momordicine I contents and levels in MCP extract. HPLC chromatogram of standard and MCP solution was shown in Figure 1. The result showed that retention times of momordicine I and MCP extract were approximately 3.5 minutes. From a standard curve (Fig. 2), the momordicine I in MCP extract was calculated to be approximately 404.9 $\mathrm{mg} / \mathrm{g}$ powdered extract.

Reproductive organ weights and sperm counts. The results showed that body and epididymis plus vas deferens weights of all groups were not different $(p>0.05)$. In contrast, testicular weight and sperm concentration in VPA group were significantly decreased as compared to control group $(p<0.05)$. Moreover, $80 \mathrm{mg} / \mathrm{kg} \mathrm{BW}$ of MCP could prevent the decrease of sperm concentration in VPA-treated rats. However, MCP-pretreated groups have no difference in testicular weight as compared with VPA group (Table III).

Protective effects of MCP extracts on testosterone level in VPA rats. As shown in Figure 3, the testosterone levels in VPA group were significantly decreased $(p<0.05)$ as compared to the control. Interestingly, such levels in all $\mathrm{MCP}+\mathrm{VAP}$ groups were significantly increased $(\mathrm{p}<0.05)$ when compared with the VPA group (Fig. 3).

Protective effects of MCP extracts on VPA-induced testicular damage. In Figure 4, seminiferous tubular atrophy and germ cell degeneration with giant cells were observed in VPA-treated rats (Fig. 4B) as compared to control (Fig. 4A). In addition, germ cell degeneration with giant cells was slightly found in MCP20+VPA and MCP40+VPA (Fig. 4C and 4D) as compared to VPA group (Fig. 4B). However, such histopathology was not found in rats treated with the high dose of MCP extract (Fig. 4E).

Level of StAR protein in testicular lysates. The immunoWestern blotting showed that StAR expression in MCP40+VPA group was obviously increased as compared to the rest groups (Fig. 5A). After analysis of StAR intensity with b -actin, StAR protein levels in only MCP40+VPA group were significantly increased when compared with the VPA group (Fig. 5B).

Protective effect of MCP on testicular tyrosine protein phosphorylation in VPA-treated rats. Testicular protein profiles by SDS-PAGE stained by Coomassie blue demonstrated that the levels of total testicular protein lysates of experimental groups were equal (Fig. 6). In immunoWestern blotting result, the expressions of testicular phosphorylated proteins in VPA group were lower than that of control (Fig. 7A). Interestingly, a 50-kDa protein band was obviously expressed in all MCP-pretreated groups (Fig. $7 \mathrm{~A})$. Corresponding to figure $7 \mathrm{~A}$, intensity of such $50-\mathrm{kDa}$ protein in all MCP-pretreated groups was significantly increased as compared to VPA group (Fig. 7B).

Table II. Levels of total phenolic contents and antioxidant capacity in the MCP aqueous extract.

\begin{tabular}{cccc} 
TPC & FRAP & Assays & DPPH \\
\hline (ug/mg garlic acid $)$ & (ug/mg ascorbic acid equivalent) & $\mathrm{IC}_{50}$ & AEAC \\
& & & $(\mathrm{ug} / \mathrm{ml})$
\end{tabular}

\begin{tabular}{lrrrr}
\hline MCP & $39.24 \pm 0.65$ & $33.08 \pm 0.21$ & $389.80 \pm 3.20$ & $1479.44 \pm 12.28$ \\
\hline
\end{tabular}

Table III. Initial and final body weights, relative weights of testis and epididymis plus vas deferens, and sperm concentration among control, VPA and MCP+VPA groups.

\begin{tabular}{lccccc}
\hline \multicolumn{1}{c}{ Parameters } & Control & VPA & MCP20+VPA & MCP40+VPA & MCP80+VPA \\
\hline Initial body weights $(\mathrm{g})$ & $179.39 \pm 15.54$ & $179.54 \pm 16.72$ & $182.25 \pm 9.84$ & $180.35 \pm 14.81$ & $179.79 \pm 14.93$ \\
Final body weights $(\mathrm{g})$ & $395.75 \pm 22.3$ & $381.50 \pm 19.80$ & $358.00 \pm 25.05$ & $345.50 \pm 26.42$ & $369.50 \pm 14.32$ \\
Testicular weights $(\mathrm{g} / 100 \mathrm{~g})$ & $0.503 \pm 0.03^{* *}$ & $0.389 \pm 0.03^{*}$ & $0.377 \pm 0.03^{*}$ & $0.368 \pm 0.03^{*}$ & $0.373 \pm 0.01^{*}$ \\
Epididym is plus vas deference weights $(\mathrm{g} / 100 \mathrm{~g})$ & $0.188 \pm 0.01$ & $0.193 \pm 0.02$ & $0.184 \pm 0.01$ & $0.163 \pm 0.01$ & $0.182 \pm 0.01$ \\
Sperm counts $\left(10^{6}\right.$ cells/ml) & $20.83 \pm 3.54^{* *}$ & $8.75 \pm 0.35^{*}$ & $13.00 \pm 3.54^{*}$ & $10.38 \pm 1.89^{*}$ & $15.75 \pm 2.90^{* *}$ \\
\hline
\end{tabular}

* Significant differences $(p<0.05)$ as compared with control group. **Significant differences $(p<0.05)$ as compared with VPA group. 


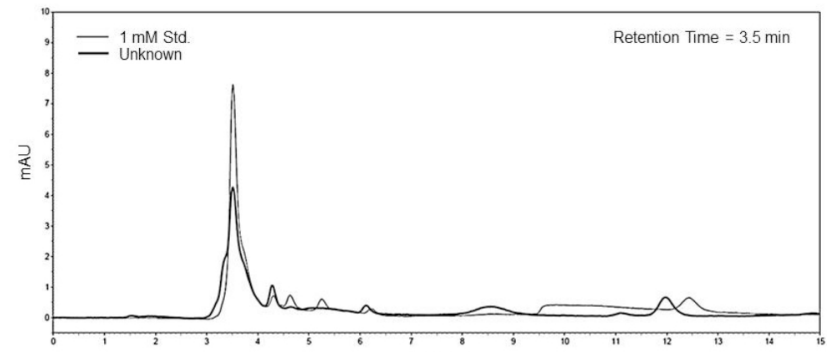

Fig. 1. HPLC chromatogram showing contents and relation times of MCP extract compared to purified momordicine I used as a standard control.

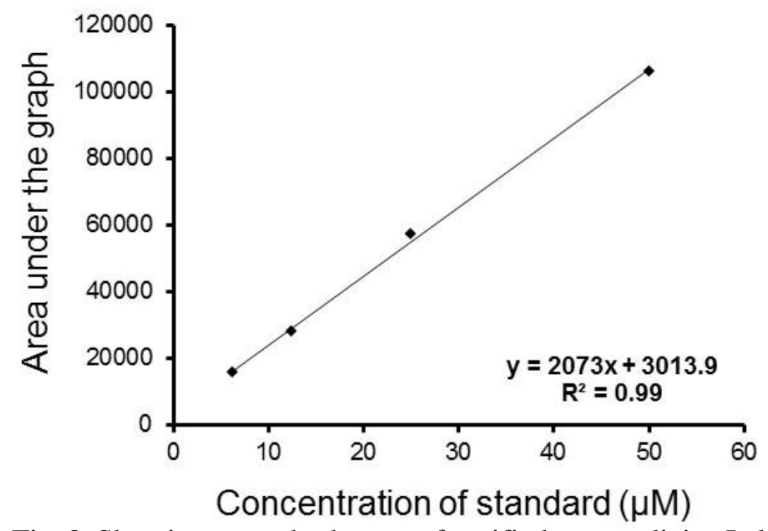

Fig. 2. Showing a standard curve of purified momordicine I plotted from four different concentrations.
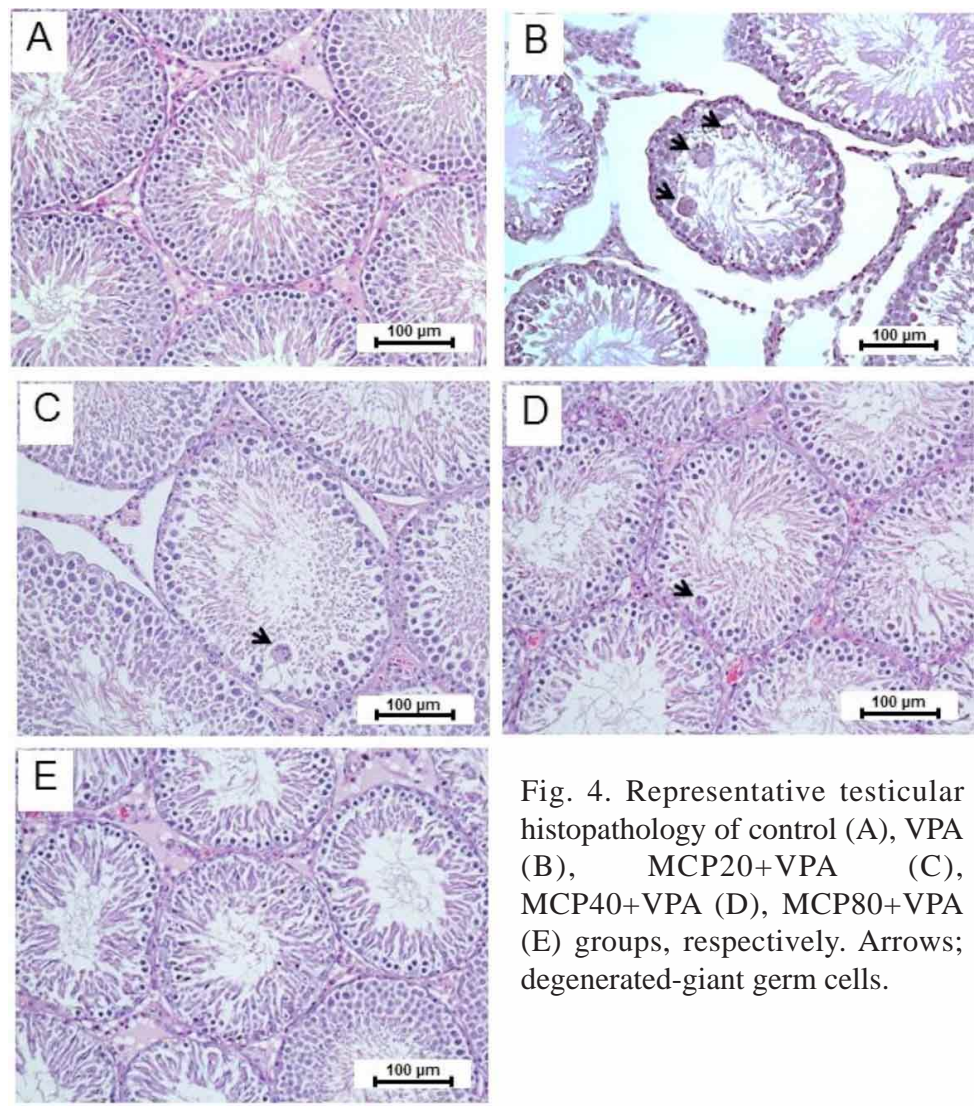

Fig. 4. Representative testicular histopathology of control (A), VPA (B), MCP20+VPA (C), MCP40+VPA (D), MCP80+VPA (E) groups, respectively. Arrows; degenerated-giant germ cells.

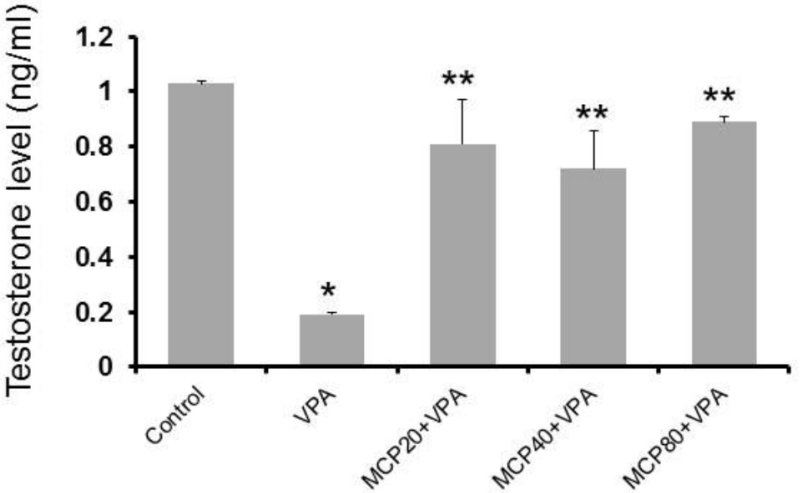

Fig. 3. Testosterone levels of control, VPA, and MCP+VPA groups (* Significant differences $(p<0.05)$ as compared with control group;

$* *$ Significant differences $(p<0.05)$ as compared with VPA group)

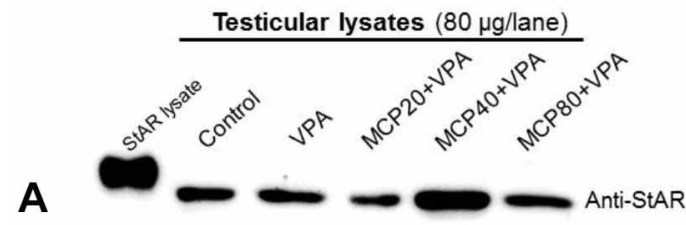

B

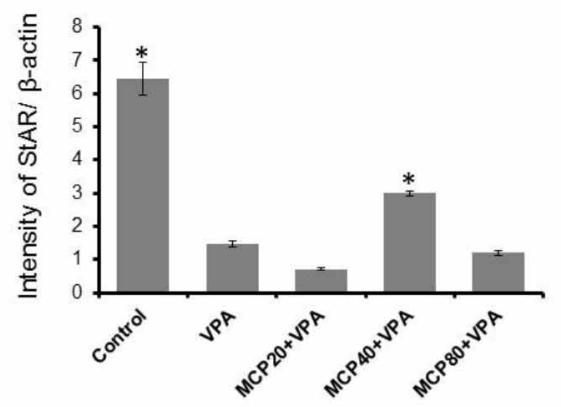

Fig. 5. The expression levels of testicular StAR proteins of all experimental groups and StAR lysate used as a positive control (A) and intensity of StAR protein per $\beta$-actin used as a internal control (B). (* Significant differences $(p<0.05)$ as compared with VPA group).

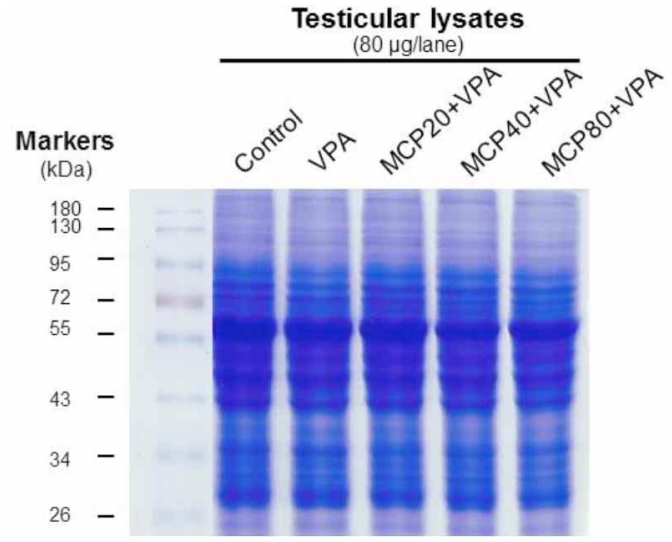

Fig. 6. SDS-PAGE stained by Coomassie blue showing equal amount of testicular protein lysate in all groups. 


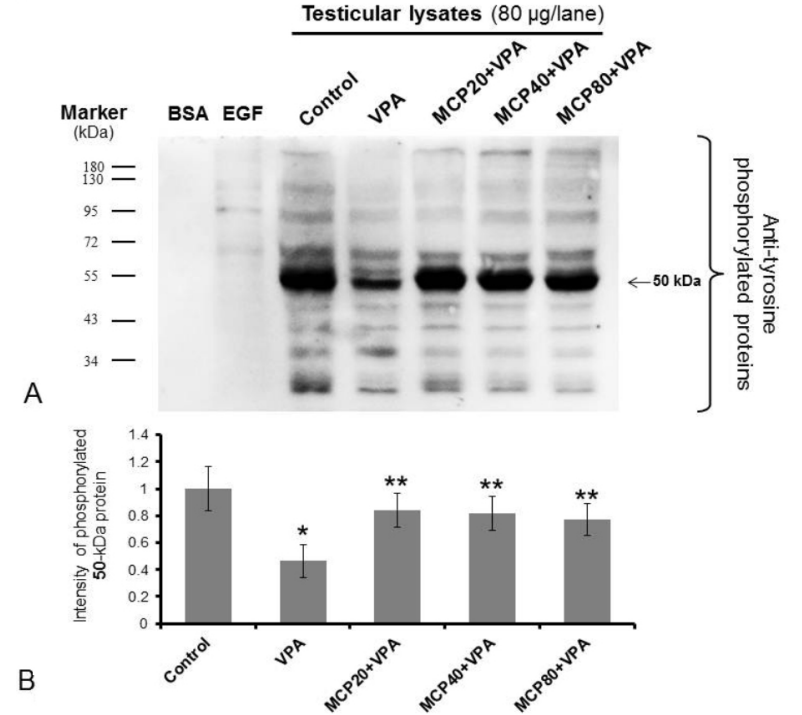

Fig. 7. The immuno-Western blot of tyrosine phosphorylated proteins (A) and intensity of a $50 \mathrm{kDa}$-phosphorylated protein (B) in testicular lysates. Bovine serum albumin (BSA); negative control and epidermal growth factor (EGF); positive control. * Significant differences $(\mathrm{p}<0.05)$ as compared with control group; **Significant differences $(\mathrm{p}<0.05)$ as compared with VPA group.

\section{DISCUSSION}

This study revealed the protective ability of MCP in VPA-induced reproductive damages including seminiferous tubular histopathology (Fig. 4), reduced testosterone level (Fig. 3 ), and decreased sperm count (Table III) in male rats. Previously, it was reported that MC extract have protective effects in liver, brain, stomach, and heart injuries (Ozbakis, Dengiz \& Gürsan; Abas et al.; Duan et al.; Deng et al.). Besides such protective effects, recent study has shown for the first time about preventive property of MCP on male reproductive impairment of VPA-treated rats. Previous reports showed the increasing of testicular malondialdehyde (MDA) level in rats induced by VPA (Hamza \& Amin; Sakr et al.; Iamsaard et al., 2017b). Indeed, the increased MDA level in VPA testis was reduced by treatments with many medicinal plant extracts possessing antioxidant activity (Hamza \& Amin; Iamsaard et al., 2015; Sukhorum et al.; Iamsaard et al., 2017b). Similar to those results, antioxidant capacity of MCP extract demonstrated (Table II) might have abilities to decrease MDA level although it was not examined in this study. It is possible that MCP containing antioxidant capacity could also increase of antioxidant enzymes such as catalase, superoxide dismutase, and glutathione peroxidase as previously reported (Hamza \& Amin; Sakr et al.). However, such lipid peroxidation markers must be further investigated to explain the real mechanism underlying of MCP preventive effects. These potential effects of MCP extract would protect VPA-testicular damage as shown in Figure 4C-E. Present study also demonstrated that MCP could prevent the decrease of StAR and tyrosine phosphorylated protein expressions which may be associated with improved sperm count (Sukhorum et al.). In fact, VPA significantly reduced gene and protein expressions of StAR, CYP11A1, and androgen receptor, responsible for testosterone production (Gustavsen et al., 2009; Glister et al.; Iamsaaed et al., 2017a). Similarly, it can be explained that the improvement of testosterone level and sperm concentration in MCP-VPA rats resulted from increasing of StAR and a 50-kDa phosphorylated protein expressions. Therefore, this study suggested that MCP extract cultured in Thailand has antioxidant activities and could protect testicular damages and reductions of sperm concentration, level of testosterone, and essential testicular proteins in VPA-induced rats.

ACKNOWLEDGEMENTS. This study was financially supported by an Invitation Grant (INb126), Faculty of Medicine, Khon Kean University, Thailand to Mr. Chanwit Maneenin, a Ph.D. candidate of anatomy program and we would like to thank HHP and HP research institute for valuable corroboration to Dr. Sitthichai Iamsaard.

MANEENIN, C.; BURAWAT, J.; MANEENIN, N.; NUALKAEW, S.; ARUN, S.; SAMPANNANG, A. \& IAMSAARD, S. Capacidad antioxidante del extracto de Momordica charantia y su efecto protector sobre el daño testicular en ratas inducidas con ácido valproico. Int. J. Morphol., 36(2):447-453, 2018.

RESUMEN: A pesar que la Momordica charantia (MC) tiene efectos preventivos sobre las lesiones en los tejidos, capacidad antioxidante y un efecto protector de la pulpa y la cáscara de MC (CMC) sobre el ácido valproico (AVP), aún no se ha informado efectos sobre el daño testicular. Las CMC frescas fueron extraídas de forma acuosa y se determinó la capacidad antioxidante y el nivel de Momordicina I por HPLC. Las ratas machos se dividieron en 5 grupos: control, AVP $(500 \mathrm{mg} / \mathrm{kg}$ de peso corporal), CMC20 / 40 / u 80 mg/kg de peso corporal + AVP. En 30 días experimentales, los animales fueron pretratados con diferentes dosis de CMC durante 20 días antes de la inyección de AVP durante 10 días consecutivos. Se investigó la concentración de espermatozoides, la hormona testosterona y la histología testicular de todos los grupos. Las expresiones de proteínas reguladoras agudas (StAR) fosforiladas con tirosina y esteroidogénicas testiculares se examinaron mediante inmunotransferencia de tipo Western. Los resultados mostraron que CMC contiene TPC (39.24 $\pm 0.65 \mathrm{ug} / \mathrm{mg}$ de ácido de ajo), capacidades antioxidantes (FRAP $=33.08 \pm 0.21 \mathrm{ug} / \mathrm{mg}$ de ácido ascórbico equivalente, IC50 de DPPH $=389.8 \pm 3.20 \mathrm{ug} / \mathrm{ml}$ ) y momordicina I (404.9 mg) / g CMC). La concentración de esperma en el grupo MCP80 + AVP aumentó en comparación con el grupo AVP. El nivel de testosterona en los grupos tratados con CMC aumentó significativamente. La CMC protegió el daño testicular y pudo prevenir la disminución de StAR y una expresión de proteína fosforilada de $50 \mathrm{kDa}$ en los testículos tratados con AVP. En conclusión, la CMC tiene efectos antioxidantes y puede prevenir la toxicidad reproductiva en ratas machos inducidas por VPA.

PALABRAS CLAVE: Momordica charantia; Momordicine I; Capacidad antioxidante; Daño testicular; Ácido valproico. 


\section{REFERENCES}

Abas, R.; Othman, F. \& Thent, Z. C. Protective effect of Momordica charantia fruit extract on hyperglycaemia-induced cardiac fibrosis. Oxid. Med. Cell. Longev., 2014:429060, 2014.

Benzie, I. F. \& Strain, J. J. The ferric reducing ability of plasma (FRAP) as a measure of "antioxidant power": the FRAP assay. Anal. Biochem., 239(1):70-6, 1996.

Berendsen, S.; Broekman, M.; Seute, T.; Snijders, T.; van Es, C.; de Vos, F.; Regli, L. \& Robe, P. Valproic acid for the treatment of malignant gliomas: review of the preclinical rationale and published clinical results. Expert Opin. Investig. Drugs, 21(9):1391-415, 2012.

Blum, A.; Loerz, C.; Martin, H. J.; Staab-Weijnitz, C. A. \& Maser, E. Momordica charantia extract, a herbal remedy for type 2 diabetes, contains a specific $11 \mathrm{~b}-$ hydroxysteroid dehydrogenase type 1 inhibitor. J. Steroid Biochem. Mol. Biol., 128(1-2):51-5, 2012.

Brand-Williams, W.; Cuvelier, M. E. \& Berset, C. Use of a free radical method to evaluate antioxidant activity. LWT Food Sci. Technol., 28(1):25-30, 1995

Burawat, J.; Uabandit, N.; Sripanidkulchai, B.; Nualkaew, S. \& Iamsaard, S. Antioxidant capacity and acute testicular toxicity of Leucaena leucocephala aqueous shoot tips plus young leaves extracts. Int. J. Morphol., 34(2):514-21, 2016.

Chew, Y. L.; Chan, E. W.; Tan, P. L.; Lim, Y. Y.; Stanslas, J. \& Goh, J. K. Assessment of phytochemical content, polyphenolic composition, antioxidant and antibacterial activities of Leguminosae medicinal plants in Peninsular Malaysia. B. M. C. Complement. Altern. Med., 11:12, 2011.

Deng, Y.; Tang, Q.; Zhang, Y.; Zhang, R.; Wei, Z.; Tang, X. \& Zhang, M. Protective effect of Momordica charantia water extract against liver injury in restraintstressed mice and the underlying mechanism. Food Nutr. Res., 61(1):1348864, 2017.

Duan, Z. Z.; Zhou, X. L.; Li, Y. H.; Zhang, F.; Li, F. Y. \& Su-Hua, Q. Protection of Momordica charantia polysaccharide against intracerebral hemorrhage-induced brain injury through JNK3 signaling pathway. J. Recept. Signal Transduct. Res., 35(6):523-9, 2015.

Gelder, M.; Harrison, P. \& Cowen, P. Shorter Oxford Textbook of Psychiatry. $5^{\text {th }}$ ed. Oxford, Oxford University Press, 2006.

Ghous, T.; Aziz, N.; Mehmood, Z. \& Andleeb, S. Comparative study of antioxidant, metal chelating and antiglycation activities of Momordica charantia flesh and pulp fractions. Pak. J. Pharm. Sci., 28(4):1217-23, 2015.

Glister, C.; Satchell, L.; Michael, A. E.; Bicknell, A. B. \& Knight, P. G. The antiepileptic drug valproic acid (VPA) inhibits steroidogenesis in bovine theca and granulosa cells in vitro. PLoS One, 7(11):e49553, 2012.

Grover, J. K. \& Yadav, S. P. Pharmacological actions and potential uses of Momordica charantia: a review. J. Ethnopharmacol,. 93(1):123-32, 2004.

Gustavsen, M. W.; von Krogh, K.; Taubøll, E.; Zimmer, K. E.; Dahl, E.; Olsaker, I.; Ropstad, E. \& Verhaegen, S. Differential effects of antiepileptic drugs on steroidogenesis in a human in vitro cell model. Acta Neurol. Scand. Suppl., (189):14-21, 2009.

Hamza, A. A. \& Amin, A. Apium graveolens modulates sodium valproate-induced reproductive toxicity in rats. J. Exp. Zool. A Ecol. Genet. Physiol., 307(4):199206, 2007.

Herzog, A. G.; Drislane, F. W.; Schomer, D. L.; Pennell, P. B.; Bromfield, E. B.; Kelly, K. M.; Farina, E. L. \& Frye, C. A. Differential effects of antiepileptic drugs on sexual function and reproductive hormones in men with epilepsy: interim analysis of a comparison between lamotrigine and enzyme-inducing antiepileptic drugs. Epilepsia, 45(7):764-8, 2004.

Iamsaard, S.; Arun, S.; Burawat, J.; Sukhorum, W.; Boonruangsri, P.; Namking, M.; Uabundit, N.; Nualkaew, S. \& Sripanidkulchai, S. Phyllanthus emblica L. branch extract ameliorates testicular damage in valproic acid-induced rats. Int. J. Morphol., 33(3):1016-22, 2015.

Iamsaard, S.; Prabsattroo, T.; Sukhorum, W.; Muchimapura, S.; Srisaard, P.; Uabundit, N.; Thukhammee, W. \& Wattanathorn, J. Anethum graveolens Linn. (dill) extract enhances the mounting frequency and level of testicular tyrosine protein phosphorylation in rats. J. Zhejiang Univ. Sci. B, 14(3):247-52, 2013.

Iamsaard, S.; Arun, S.; Burawat, J.; Sukhorum, W.; Wattanathorn, J.; Nualkaew, S. \& Sripanidkulchai, B. Phenolic contents and antioxidant capacities of ThaiMakham Pom (Phyllanthus emblica L.) aqueous extracts. J. Zhejiang Univ. Sci. B, 15(4):405-8, 2014.
Iamsaard, S.; Sukhorum, W.; Arun, S.; Phunchago, N.; Uabundit, N.; Boonruangsri, P. \& Namking, M. Valproic acid induces histologic changes and decreases androgen receptor levels of testis and epididymis in rats. Int. J. Reprod. Biomed. (Yazd), 15(4):217-24, 2017a.

Iamsaard, S.; Sukhorum, W.; Sampannang, A. \& Sripanidkulchai, B. Protective effect of Momordica cochinchinensis (L.) spreng aril extract on essential testicular markers in rats induced with valproic acid. Int. J. Morphol., 35(3):992-9, 2017b.

Isojärvi, J. Disorders of reproduction in patients with epilepsy: antiepileptic drug related mechanisms. Seizure, 17(2):111-9, 2008.

Jentink, J.; Loane, M. A.; Dolk, H.; Barisic, I.; Garne, E.; Morris, J. K.; de Jongvan den Berg, L. T. \& EUROCAT Antiepileptic Study Working Group. Valproic acid monotherapy in pregnancy and major congenital malformations. $N$. Engl. J. Med., 362(23):2185-93, 2010.

Khan, S.; Ahmad, T.; Parekh, C. V.; Trivedi, P. P.; Kushwaha, S. \& Jena, G. Investigation on sodium valproate induced germ cell damage, oxidative stress and genotoxicity in male Swiss mice. Reprod. Toxicol., 32(4):385-94, 2011.

Lee-Huang, S.; Huang, P. L.; Chen, H. C.; Huang, P. L.; Bourinbaiar, A.; Huang, H. I. \& Kung, H. F. Anti-HIV and anti-tumor activities of recombinant MAP30 from bitter melon. Gene, 161(2):151-6, 1995.

Löscher, W. Basic pharmacology of valproate: a review after 35 years of clinical use for the treatment of epilepsy. C. N. S. Drugs, 16(10):669-94, 2002.

Nishimura, T.; Sakai, M. \& Yonezawa, H. Effects of valproic acid on fertility and reproductive organs in male rats. J. Toxicol. Sci., 25(2):85-93, 2000.

Ozbakis, Dengiz, G. \& Gürsan, N. Effects of Momordica charantia L. (Cucurbitaceae) on indomethacin-induced ulcer model in rats. Turk. J. Gastroenterol., 16(2):85-8, 2005.

Sakr, S. A.; Zowail, M. E. \& Marzouk, A. M. Effect of saffron (Crocus sativus L.) on sodium valporate induced cytogenetic and testicular alterations in albino rats. Anat. Cell Biol., 47(3):171-9, 2014.

Singleton, V. L.; Orthofer, R. \& Lamuela-Raventós, R. M. Analysis of Total Phenols and other Oxidation Substrates and Antioxidants by Means of Folin-Ciocalteu Reagent. In: Packer, L. (Ed.). Methods in Enzymology. San Diego, Academic Press, 1999. pp.152-78.

Sukhorum, W. \& Iamsaard, S. Changes in testicular function proteins and sperm acrosome status in rats treated with valproic acid. Reprod. Fertil. Dev. 29(8):1585-92, 2017.

Sukhorum, W.; Sampannang, A.; Sripanidkulchai, B. \& Iamsaard, S. Momordica cochinchinensis (L.) Spreng. Aril extract prevents adverse reproductive parameters of male rats induced with valproic acid. Int. J. Morphol., 34(3):8706, 2016.

Taubøll, E.; Røste, L. S.; Svalheim, S. \& Gjerstad, L. Disorders of reproduction in epilepsy--what can we learn from animal studies? Seizure, 17(2):120-6, 2008.

Watkins, R. J.; Gough, A. W.; McGuire, E. J.; Goldenthal, E. \& de la Iglesia, F. A. Calcium valproate-induced uterine adenocarcinomas in Wistar rats. Toxicology, 71(1-2):35-47, 1992.

Witczak, M.; Kociszewska, I.; Wilczynski, J.; Lopaczynska, D. \& Ferenc, T. Evaluation of chromosome aberrations, sister chromatid exchange and micronuclei in cultured cord-blood lymphocytes of newborns of women treated for epilepsy during pregnancy. Mutat. Res., 701(2):111-7, 2010.

Corresponding author:

Sitthichai lamsaard

Department of Anatomy

Faculty of Medicine

Khon Kaen University

Khon Kaen, 40002

THAILAND

Email: sittia@kku.ac.th

Received: 30-10-2107

Accepted: 30-01-2018 